\title{
PERAN CITRA MEREK, HARGA DAN KEMASAN TERHADAP KEPUTUSAN PEMBELIAN AIR MINUM DALAM KEMASAN AQUA
}

\author{
Rizal Maulana Ismuputro \\ Universitas Negeri Surabaya \\ rizalismuputro@mhs.unesa.ac.id
}

\begin{abstract}
Various water products include packaging made for customers needed, one of them is an Aqua. Aqua is the main drinking product from PT. Aqua Golden Mississipi. According to Top Brand Index in 2017 until 2019, Aqua can be a brand leader of bottled water producers. This research aims to discuss images of the brand, price, and packaging for drinking water purchasing decisions of Aqua in Surabaya. The data of the study were analyzed using multiple linear regression techniques. The result out of research shows that the effects of brand image on purchase decisions but the packaging variable will not influence the purchase decision. In this research dominated effect is the variable brand image.
\end{abstract}

Keywords: brand image; decision of purchase; packaging; price.

\section{PENDAHULUAN}

Persaingan dunia bisnis semakin ketat di era globalisasi ini. Perkembangan perekonomian nasional berakibat semakin berkembangnya produk yang ditawarkan di pasar. Perusahaan dituntut harus mampu mengimbangi persaingan tersebut agar dapat bertahan di pasar yang semakin kompetitif salah satunya adalah industri Air Minum Dalam Kemasan (AMDK). Pernyataan yang disampaikan oleh ketua Asosiasi AMDK atau ASPADIN, pertumbuhan konsumsi di dalam negeri meningkat sebesar 9\% di bandingkan dengan pertumbuhan konsumsi di tahun lalu (kontan.co.id, 2019). PT.Aqua Golden Mississippi adalah sebuah perusahaan yang bergerak di bidang pangan. PT.Aqua Golden Mississippi memproduksi sebagian besar produk pangan berupa Air Minum Dalam Kemasan (AMDK) di Indonesia. PT.Aqua Golden Mississippi menjadi pionir produsen Air Minum Dalam Kemasan (AMDK) di Indonesia (Husaini, 2018).

Berdasarkan data dari Top Brand Index tahun 2016-2019 produk Aqua masih menjadi pemimpin pasar yang di minati oleh para konsumen selama 4 tahun. Dimana presentase produk lain seperti Ades, Club, Le Minerale, Cleo, 2 tang dan Vit masih jauh di bawah Aqua. Hal ini menunjukkan bahwa PT. Aqua Golden Mississipi dengan produk Aqua berhasil menjadi produk yang digemari oleh konsumen berdasarkan survei dari Top Brand Index. Berdasarkan data presentase TopBrand Index dari Aqua mengalami peningkatan dibandingkan dari produk yang lain. Top Brand Index sendiri dapat diukur dari 3 faktor yaitu top of mind, last usage dan future intentions. Dalam hal ini Aqua membagi ke dalam 3 faktor pengukuran antara lain yang pertama top of mind, Aqua memiliki banyak keunggulan salah satunya yaitu slogan "Kebaikan Berawal Dari Sini" yang selalu tertanam pada benak konsumen. Citra merek Aqua dinilai lebih unggul daripada Air Minum Dalam Kemasan lainnya dikarenakan sumber mata air Aqua di dapat dari pegunungan terpilih. Yang kedua last usage, berdasarkan produk Aqua yang sering dibeli oleh konsumen yaitu Air Minum Dalam Kemasan Aqua berukuran $600 \mathrm{ml}$ di karenakan pada ukuran tersebut konsumen merasa cukup untuk memenuhi kebutuhan dehidrasi tubuh. Yang ketiga future intentions, dikarenakan setiap manusia sangat membutuhkan air minum untuk menunjang kebutuhan seseorang dalam beraktifitas.

Oleh karena itu, citra dari perusahaan sangat diperlukan karena faktor penting yang bisa mempengaruhi seorang konsumen untuk menentukan keputusan pembelian. Semua produsen Air Minum Dalam Kemasan harus memiliki strategi yang baik agar dapat menarik konsumen untuk melakukan pembelian tersebut. Keputusan pembelian pada konsumen terhadap sebuah produk/barang sangat penting karena dengan melakukan pembelian maka evaluasi paska pembelian terjadi (Kotler, 2007:201). Penelitian ini menggunakan pengukuran citra merek yang berdasar pada Keller (2013:326) 
antara lain kekuatan asosiasi merek, keuntungan asosiasi merek dan keunikan asosiasi merek. PT. Aqua Golden Mississippi ingin mempertahankan citra merek yang dimiliki terhadap produknya yaitu Aqua. Adapun penelitian yang membahas mengenai objek penelitian ini. Nofrian (2016) dan Sukotjo (2016) mengemukakan bahwa citra merek berpengaruh terhadap keputusan pembelian. Namun menurut Berlian (2007), citra merek tidak berpengaruh terhadap keputusan pembelian.

Selain citra merek, harga produk Aqua juga menjadi pertimbangan bagi setiap konsumen. Menurut pra penelitian yang dilakukan dengan responden sebanyak 39 orang menyatakan bahwa harga Aqua menjadi pertimbangan konsumen untuk melakukan pembelian. Harga sangat berpengaruh dengan keputusan pembelian dapat dilihat dari kualitas Air Minum Dalam Kemasan. Semakin baik kualitas produk Air Minum Dalam Kemasan maka harga yang diberikan juga semakin mahal. Menurut Nur Hidayat (2017), Hustić \& Gregurec (2015) dan Kamanda (2015), harga berpengaruh terhadap keputusan pembelian. Tetapi menurut Ningsih et al (2015), harga tidak berpengaruh terdapat keputusan pembelian. Adapun daftar harga Air Minum Dalam Kemasan yang diproduksi produsen di Indonesia sebagai berikut.

Tabel 1.

HARGA AIR MINUM DALAM KEMASAN DI INDONESIA

\begin{tabular}{|c|c|c|c|}
\hline Merek AMDK & 240ml (Gelas)/Dus & $\begin{array}{c}\text { Varian } \\
600 \mathrm{ml} \text { (Botol) }\end{array}$ & $1500 \mathrm{ml}$ (Botol) \\
\hline Aqua & $\operatorname{Rp} 30.000$ & $\operatorname{Rp} 3.500$ & $\operatorname{Rp} 5.800$ \\
\hline Cleo & Rp 19.000 & Rp 2.700 & $\operatorname{Rp} 5.700$ \\
\hline Club & Rp 20.000 & $\operatorname{Rp} 3.200$ & Rp 5.600 \\
\hline Crystalline & Rp 21.000 & Rp 2.800 & Rp 5.000 \\
\hline Ades & - & $\operatorname{Rp} 3.400$ & Rp 5.900 \\
\hline Le Minerale & - & $\operatorname{Rp} 3.400$ & $\operatorname{Rp} 5.500$ \\
\hline
\end{tabular}

Sumber: katalogkjsm.com (2019)

Dari tabel 1, Aqua masih menjadi produk yang sedikit lebih mahal dibandingkan produk lain seperti Cleo, Club, Crystalline, Ades dan Le minerale. Terdapat perbedaan akan harga produk menurut tabel di atas. Selain citra merek dan harga yang dimiliki oleh Aqua. Selain itu, kemasan aqua memiliki berbagai macam desain setiap tahunnya seperti Temukan Indonesiamu, Disney, Teka-Teki, dan lain sebagainya yang membuat konsumen lebih tertarik (indopress.id, 2019). Kemasan dari Aqua mudah diingat oleh konsumen karena label dan warna dalam kemasan Aqua tidak berubah.

Adapun penelitian yang membahas tentang pengaruh sebuah kemasan terhadap seseorang untuk menentukan keputusan pembelian. Menurut Maulana (2019), Zemuy (2013) dan Puadah (2015), kemasan berpengaruh terhadap keputusan pembelian Air Minum Dalam Kemasan. Tetapi menurut Aminati (2016), kemasan tidak berpengaruh terhadap keputusan pembelian Air Minum Dalam Kemasan.

Penelitian ini bertujuan mengetahui pengaruh citra merek, harga dan kemasan terhadap keputusan pembelian.

\section{KAJIAN PUSTAKA DAN PENGEMBANGAN HIPOTESIS}

\section{Citra Merek}

Berdasarkan teori dari Kotler \& Keller (2009:406), arti dari sebuah citra merek adalah mengatur kepercayaan konsumen pada merek-merek tertentu. Itu artinya konsumen yang telah menilai citra positif terhadap merek akan lebih cenderung melakukan pembelian. Dalam penelitian ini untuk menentukan indikator variabel Citra Merek memakai metode Free Association dari Keller (2013:326) yaitu kekuatan asosiasi merek, keuntungan asosiasi merek dan keunikan asosiasi merek. 
Rizal Maulana Ismuputro. Peran Citra Merek, Harga Dan Kemasan terhadap Keputusan Pembelian Air Minum Dalam Kemasan Aqua

\section{Harga}

Berdasarkan teori dari Tjiptono (2012:315), arti dari harga adalah satuan yang dapat menentukan jumlah uang dan aspek yang lain (non-moneter) serta memiliki kegunaan khusus yang digunakan untuk memperoleh sesuatu. Adapun indikator menurut McCarthy \& D (2002:90) yaitu tingkat harga, potongan harga, waktu pembayaran dan syarat pembayaran. Adapun indikator harga menurut Kamanda (2015) yaitu keterjangkauan harga, kesesuaian harga dengan kualitas produk, daya saing harga dan kesesuaian harga dengan manfaat. Dari beberapa teori jurnal di atas, maka untuk mengukur variabel harga dengan menggunakan indikator menurut penelitian dari Kamanda (2015) yaitu keterjangkauan harga, kesesuaian harga dengan kualitas produk dan daya saing harga.

\section{Kemasan}

Berdasarkan teori dari Kotler \& Amstrong (2008:275), arti dari kemasan adalah aktivitas merancang dan memproduksi wadah atau pembungkus suatu produk. Kemasan yang menarik dapat memberikan nilai tambah untuk konsumen yang dapat membedakan beberapa produk yang bentuk dan mutunya hampir sama. Adapun indikator kemasan menurut Guntur (2014) yaitu warna kemasan, struktur fisik dari bentuk dari kemasan, logo yang terdapat dalam kemasan dan tulisan yang terdapat dalam kemasan. Dari beberapa teori di atas, untuk mengukur variabel kemasan menggunakan indikator menurut Guntur (2014) yaitu warna kemasan, logo yang terdapat dalam kemasan dan tulisan yang terdapat dalam kemasan.

\section{Keputusan Pembelian}

Berdasarkan teori dari Tjiptono (2008:21), arti dari keputusan pembelian adalah suatu proses konsumen untuk mengenali masalahnya, mencari informasi tentang sebuah produk dan mengevaluasi mana dari semua alternatif tersebut baik untuk memecahkan masalah dari seorang konsumen, setelah itu mengarah untuk melakukan keputusan pembelian. Berdasarkan teori dari Kotler \& Keller (2009:99) indikator dari keputusan pembelian yaitu keputusan membeli produk dengan merek tersebut sudah tepat, membeli produk yang sudah sesuai dengan kebutuhannya dan keyakinan terhadap keputusannya dalam membeli produk dengan merek tersebut. Tetapi Ningsih et al (2015) menggunakan indikator keputusan pembelian yaitu kemantapan pada sebuah produk, kebiasaan dalam membeli produk, memberikan rekomendasi kepada orang lain dan melakukan pembelian ulang. Dari beberapa teori di atas maka untuk mengukur variabel keputusan pembelian menggunakan indikator menurut Ningsih et al (2015) yaitu kebiasaan dalam membeli produk dan melakukan pembelian ulang.

\section{Hubungan antar Variabel}

Citra merek adalah persepsi konsumen secara keseluruhan, dimulai dari kemasan hingga kualitas produk dalam sebuah merek (Kotler, 2007:201). Citra terhadap merek saling berhubungan dengan sebuah sikap berupa preferensi dan keyakinan terhadap suatu merek. Sebuah merek yang baik dapat menjadi dasar untuk membangun citra yang baik bagi sebuah produsen. Citra konsumen yang ppositif akan lebih membuat konsumen untuk melakukan pembelian. Semakin baik Citra Merek dalam suatu produk akan semakin tinggi konsumen untuk melakukan keputusan pembelian terhadap produk tersebut. (Nofrian, 2016) mengemukakan bahwa citra merek berpengaruh terhadap keputusan pembelian. Hal ini berarti setiap meningkatnya kualitas citra merek maka keputusan pembelian dalam membeli produk akan meningkat secara signifikan. Hasil penelitian ini juga didukung oleh Selestio (2013) mengemukakan bahwa citra merek berpengaruh signifikan terhadap Keputusan Pembelian.

H1: Ada pengaruh citra merek terhadap keputusan pembelian Air Minum Dalam Kemasan Aqua di Surabaya.

Harga adalah sebagai suatu nilai yang dimiliki terhadap suatu produk atau jasa yang digunakan sebagai tolak ukur setiap konsumen untuk melakukan pembelian (McCarthy \& D, 2002). Harga terjangkau dapat meningkatkan keinginan konsumen untuk membeli produk yang ditawarkan secara berkala. Hal tersebut juga dapat meningkatkan tingkat penjualan perusahaan karena semakin harga yang cenderung miring. Menurut Nur Hidayat (2017), harga berpengaruh terhadap keputusan pembelian. Menurut Kamanda (2015), harga berpengaruh terhadap keputusan pembelian. 
H2: Ada pengaruh harga terhadap keputusan pembelian Air Minum Dalam Kemasan Aqua di Surabaya.

Berdasarkan teori dari Kotler \& Armstrong (2008:275), arti kemasan adalah aktivitas merancang dan memproduksi wadah suatu produk. Bungkus atau kemasan yang menarik akan memberikan nilai plus pada konsumen yang sedang membedakan beberapa produk yang bentuk dan mutunya hampir sama. Selain itu kemasan yang menarik akan membuat konsumen tertarik untuk membeli. Menurut Guntur (2014), kemasan berpengaruh terhadap keputusan pembelian. Menurut Maulana (2019), kemasan berpengaruh dengan keputusan pembelian.

H3: Ada pengaruh kemasan terhadap keputusan pembelian Air Minum Dalam Kemasan Aqua di Surabaya.

\section{METODE PENELITIAN}

Jenis penelitian ini adalah penelitian konsklusif. Data yang digunakan untuk penelitian ini adalah data primer serta data sekunder. Variabel bebas yaang terdapat pada penelitian ini adalah citra merek, harga dan kemasan. Sedangkan variabel terikat dalam penelitian ini adalah keputusan pembelian. Populasi penelitian ini adalah masyarakat yang sudah pernah mengonsumsi Air Minum Dalam Kemasan Aqua yang bertempat di Surabaya dengan umur di atas 17 tahun. Jumlah sampel penelitian ini adalah 110 orang. Media penelitian yang digunakan adalah kuesioner yang dibagikan online lewat Google Form yang disebar melalui media sosial seperti Whatsapp, Instagram dan Twitter.

Lokasi pengambilan data dilakukan di Surabaya karena Surabaya adalah kota terbesar dan terpadat kedua setelah Jakarta. Surabaya memiliki jumlah penduduk sekitar 3 juta lebih (surabayakota.bps.go.id, 2019). Responden dari penelitian ini adalah orang dewasa pada umur 17 tahun ke atas dikarenakan pada umur 17 tahun ke atas seseorang dapat menentukan keputusan pembelian sendiri (Murty, 2019).

Teknik pengambilan sampel penelitian ini menggunakan purposive sampling, teknik yang digunakan penelitian ini adalah judgemental sampling yang dipilih dari responden awal kemudian dilakukan uji validitas dan reliabilitas terhadap insturemen penelitian yang akan digunakan. Setelah lolos uji ini, selanjutnya akan disebar untuk memperoleh 110 responden yang selanjutnya dilakukan uji validitas dan reliabilitas kembali untuk mengetahui jawaban responden valid dan reliabel dengan harapan dapat lolos uji asumsi klasik dan memenuhi model regresi linier berganda. Data yang terkumpul dianalisis dengan regresi linier berganda dengan menggunakan uji asumsi klasik yaitu uji normalitas, uji multikolinieritas dan uji heterokedastisitas. Selanjutnya, data akan diproses dengan uji hipotesis dengan menggunakan Uji t \& uji koefisien determinasi.

\section{HASIL DAN PEMBAHASAN}

\section{Uji Validitas}

Uji validitas sebelumnya dilakukan kepada 30 responden dengan menggunakan kuisioner sebagai Pretest untuk mengukur kualitas angket yang akan disebar pada jumlah sampel yang telah ditentukan. Kemudian dilanjutkan dengan Uji Validitas kepada 110 responden dengan hasil semua data dengan hasil rTabel > 0,30 dan dikatakan valid serta data sudah reliabel dengan nilai Cronbach Alpha >0,70. Uji normalitas yang lebih besar dari 0,05 yaitu sebesar 0,200. Dengan demikian, data yang diperoleh dapat dinyatakan berdistribusi normal.

\section{Uji Multikolonieritas}

Uji multikolonieritas menunjukkan bahwa nilai Tolerance dari variabel citra merek yaitu $0,428 \geq$ 0,100 , variabel harga yaitu $0,688 \geq 0,100$ dan variabel kemasan yaitu $0,421 \geq 0,100$. Hasil tersebut menunjukkan tidak terjadi multikolinieritas antar variabel independen. Nilai VIF dari masing-masing variabel independen yaitu untuk variabel citra merek $2,336 \leq 10,00$, variabel harga yaitu $1,454 \leq$ 
Rizal Maulana Ismuputro. Peran Citra Merek, Harga Dan Kemasan terhadap Keputusan Pembelian Air Minum Dalam Kemasan Aqua

10,00 dan variabel kemasan yaitu $2,377 \leq 10,00$. Dengan demikian dalam penelitian ini tidak memiliki korelasi yang kuat antar variabel independen. Uji heterokedastisitas berdasarkan grafik scatterplot menunjukkan bahwa titik-titik tidak menggambarkan pola dan menyebar di antara angka nol pada sumbu Y. Sehingga, model regresi tidak terjadi heterokesdasitas.

\section{Uji Regresi Linier Berganda}

Hasil analisis regresi linear berganda yaitu nilai koefisien variabel citra merek adalah 0,148 dan positif $(+)$ membuktikan citra merek $\left(\mathrm{X}_{1}\right)$ dan keputusan pembelian $(\mathrm{Y})$ memiliki pengaruh yang positif. Nilai koefisien untuk variabel harga adalah 0,331 dan bernilai positif yang membuktikan harga $\left(\mathrm{X}_{2}\right)$ dan keputusan pembelian $(\mathrm{Y})$ memiliki pengaruh yang positif. Nilai koefisien untuk variabel kemasan adalah $-0,036$ dan bernilai negatif yang membuktikan kemasan $\left(\mathrm{X}_{3}\right)$ dan keputusan pembelian (Y) memiliki pengaruh yang negatif.

\section{Uji T}

Hasil uji t membuktikan nilai t hitung untuk variabel citra merek (X1) adalah sebesar 3,468 lebih besar dari t tabel yaitu 1,982 bernilai signifikan sebesar 0,001 yang lebih kecil dari 0,05 atau 5\% maka H0 ditolak dan H1 diterima. Sehingga dapat dikatakan bahwa terdapat pengaruh positif antara citra merek terhadap keputusan pembelian. Pada hasil uji t untuk variabel harga (X2) adalah sebesar 3,163 lebih besar dari t tabel yaitu 1,982 dengan nilai signifikan sebesar 0,002 yang lebih kecil dari 0,05 atau 5\% maka H0 ditolak dan $\mathrm{H} 1$ diterima. Sehingga dapat dikatakan bahwa terdapat pengaruh positif antara harga terhadap keputusan pembelian. Pada hasil uji t variabel kemasan (X3) adalah sebesar 0,282 lebih kecil dari t tabel yaitu 1,982 dengan nilai signifikan sebesar 0,778 yang lebih besar dari 0,05 atau $5 \%$ maka H0 diterima dan H1 ditolak. Sehingga, dapat dibuktikan bahwa tidak adanya pengaruh antara kemasan terhadap keputusan pembelian.

\section{Uji Kelayakan Model}

Berdasarkan tabel 2 hasil uji kelayakan model dapat diketahui bahwa besarnya kontribusi citra merek (X1), harga (X2) dan Kemasan (X3) mempengaruhi keputusan pembelian (Y) sebesar 0,337 atau $33,7 \%$. Sedangkan sisanya $66,3 \%(100 \%-33,7 \%=66,3 \%)$ dipengaruhi oleh variabel di luar variabel yang digunakan dalam penelitian ini seperti kualitas produk.

Tabel 2.

HASIL UJI KELAYAKAN MODEL

\begin{tabular}{llrrr}
\hline Model & R & R Square & Adjusted R Square & Std. Error of the Estimate \\
\hline 1 &, $596^{\mathrm{a}}$ &, 356 &, 337 & 2,93535 \\
\hline
\end{tabular}

Sumber: Output IBM SPSS 25

\section{Pengaruh Citra Merek (X1) terhadap Keputusan Pembelian (Y)}

Berdasarkan hasil penelitian ini menujukan adanya pengaruh positif antar variabel citra merek (X1) dan keputusan pembelian (Y) Air Minum Dalam Kemasan Aqua, artinya terdapat pengaruh positif antara citra merek terhadap keputusan pembelian. Sehingga semakin baik citra merek yang diterima oleh responden maka semakin cepat responden melakukan keputusan pembelian sebuah produk.

Nofrian (2016) dan Oladepo \& Abimbola (2015) mengemukakan bahwa citra merek berpengaruh terhadap keputusan pembelian. Tetapi menurut (Berlian, 2007) mengemukakan bahwa citra merek tidak berpengaruh terhadap keputusan pembelian. Citra merek sendiri menggunakan indikator yaitu kekuatan asosiasi merekkeuntungan asosiasi merek dan keunikan asosiasi merek.

Berdasarkan hasil responden dalam penelitian ini, sebagian besar responden mengungkapkan bahwa citra merek yang dimiliki Aqua sangat baik. Dalam penelitian ini mengukur variabel citra merek menggunakan tiga indikator yang mengacu pada Keller (2013:40) yaitu strength of brand association (kekuatan asosiasi merek), favorable of brand association (keuntungan asosiasi merek), dan uniques of brand association (keunikan asosiasi merek). Mayoritas responden sangat setuju Aqua memiliki 
citra merek yang kuat. Hal ini dikarenakan citra merek yang terbentuk dari citra produk yang dimiliki Aqua sangat baik yang akan mempengaruhi keputusan pembelian.

PT.Aqua Golden Mississipi sendiri menciptakan produk Aqua untuk memenuhi kebutuhan air minum masyarakat. PT. Aqua Golden Mississipi juga sangat memperhatikan citra yang sudah dimiliki karena citra merek sendiri sangat mempengaruhi konsumen untuk melakukan pembelian air minum. Karakteristik responden dalam penelitian ini yang terbanyak pada umur 17 hingga 25 tahun. Hal ini dikarenakan pada umur 17 hingga 25 tahun banyak melakukan aktifitas yang menyebabkan dehidrasi.

\section{Pengaruh Harga (X2) terhadap Keputusan Pembelian (Y)}

Hasil penelitian menunjukan bahwa terdapat pengaruh positif antara harga (X2) dengan keputusan pembelian (Y) Air Minum Dalam Kemasan Aqua artinya terdapat pengaruh positif antara harga (X2) dengan keputusan pembelian (Y). Sehingga semakin sesuai harga yang diterima oleh responden maka responden akan semkain cepat untuk memilih produk yang tepat untuk melakukan keputusan pembelian.

Selain itu, hasil penelitian menurut Hidayat (2017) menunjukkan bahwa harga berpengaruh terhadap keputusan pembelian. Hasil ini diperkuat oleh penelitian yang dilakukan oleh (Hustić \& Gregurec, 2015) mengemukakan bahwa harga berpengaruh terhadap keputusan pembelian. Tetapi, menurut Ningsih et al (2015) mengemukakan bahwa harga tidak berpengaruh terdapat keputusan pembelian.

Dalam penelitian in pengukuran variabel harga menggunakan tiga indikator, yaitu keterjangkauan harga, kesesuaian harga dengan kualitas produk dan daya saing harga. Mayoritas responden setuju jika harga Aqua botol sesuai dengan kualitas produk yang dirasakan oleh konsumen. Dalam penelitian ini, peneliti meneliti responden dengan umur minimal 17 tahun. Hal ini dikarenakan seorang responden pada umur 17 tahun keatas dapat menentukan keputusan pembeliannya sendiri.

\section{Pengaruh Kemasan (X3) terhadap Keputusan Pembelian (Y)}

Berdasarkan hasil penelitian menunjukan bahwa tidak terdapat pengaruh antara kemasan (X3) dengan keputusan pembelian (Y) Air Minum Dalam Kemasan Aqua artinya tidak terdapat pengaruh antara kemasan (X3) dengan keputusan pembelian (Y). Sehingga kemasan pada produk Aqua botol bukan menjadi pertimbangan utama konsumen untuk melakukan keputusan pembelian. Aqua memiliki berbagai inovasi kemasan setiap tahunnya. Seperti desain kemasan bertema Temukan Indonesiamu, Disney, teka-teki, dan lain sebagainya. Dengan adanya berbagai inovasi kemasan yang dikeluarkan oleh PT.Aqua Golden Mississipi, para konsumen tertarik dan membeli produk Aqua (Husaini, 2018).

Hasil penelitian ini mendukung peneliti yang dilakukan oleh Aminati (2016) mengemukakan bahwa kemasan tidak berpengaruh terhadap keputusan pembelian.. Namun penelitian ini tidak mendukung penelitian yang dilakukan oleh Zemuy (2013) mengemukakan bahwa kemasan berpengaruh terhadap keputusan pembelian. Tetapi menurut Maulana (2019) mengemukakan bahwa kemasan berpengaruh terhadap keputusan pembelian.

Dalam penelitian ini, pengukuran variabel kemasan menggunakan tiga indikator, yaitu warna kemasan, logo yang terdapat dalam kemasan dan tulisan yang terdapat dalam kemasan. Mayoritas responden sangat setuju warna tulisan yang ada di botol Aqua mudah diingat.

\section{KESIMPULAN}

Berdasarkan hasil penelitian dan pembahasan dari analisis data jawaban responden dapat disimpulkan bahwa citra merek dan harga berpengaruh terhadap keputusan pembelian Air Minum Dalam Kemasan Aqua pada masyarakat Surabaya. Namun kemasan tidak berpengaruh terhadap keputusan pembelian Air Minum Dalam Kemasan Aqua pada masyarakat Surabaya. Citra merek memilliki pengaruh yang lebih besar dibandingkan dengan harga dan kemasan terhadap keputusan pembelian. 
Rizal Maulana Ismuputro. Peran Citra Merek, Harga Dan Kemasan terhadap Keputusan Pembelian Air Minum Dalam Kemasan Aqua

Penelitian ini masih memiliki keterbatasan dalam hal penyebaran angket. Penelitian ini tidak menyediakan angket terbuka terkait citra merek, harga dan kemasan sehingga pembahasan yang diberikan kurang mendalam. Cara pengumpulan data responden hanya menggunakan angket online yang dirasa kurang efektif karena banyak responden masuk yang bertempat tinggal di luar Surabaya. Penelitian selanjutnya dapat melibatkan variabel kualitas produk.

\section{DAFTAR PUSTAKA}

Aminati, D. (2016). Pengaruh Packaging Color, Packaging Material, Design Of Wrapper Dan Innovation Terhadap Keputusan Pembelian Pada Produk Air Mineral Indomaret.

Berlian, K. (2007). Pengaruh Brand Image "BSF" terhadap Keputusan Pembelian Air Minum Dalam Kemasan di Kota Bandung.

Guntur, T. T. (2014). Pengaruh Brand Image Dan Package Terhadap Keputusan Pembelian Pada Air Minum Kemasan Merek Aqua Di Fakultas Ekonomi Jurusan Manajemen Universitas Medan Area.

Hustić, I., \& Gregurec, I. (2015). The Influence Of Price On Customer's Purchase Decision. Central European Conference On Information And Intelligent Systems,

Husaini, A. (2018). Serba-Serbi Aqua. indopress.id. (www.indopress.id/article/serbaserbi/desainkemasan-aqua-unggulkan-ilustrasi, diakses pada Juni 2018).

Kamanda, S. V. (2015). Pengaruh Citra Merek Dan Harga Terhadap Keputusan Pembelian Air Minum Merek Aqua Pada Mahasiswa Fakultas Ekonomi Universitas Medan Area Medan.

Keller, K. L. (2013). Strategic Brand Management Building Measuring and Managing Brand Equity (4th ed.). USA:Pearson Education.

Hidayat, A (2019). Bisnis Air Minum Kemassan Diprediksi Bakal Meningkat Tahun Depan. kontan.id. (https://industri.kontan.co.id/news/bisnis-air-minum-kemasan-diprediksi-bakalmeningkat-tahun-depan, diakses pada Juli 2019)

Kotler \& Armstrong. (2008). Prinsip-Prinsip Pemasaran (12th ed.). Surabaya:Erlangga.

Kotler \& Keller. (2009). Manajemen Pemasaran (13th ed.). Surabaya:Erlangga.

Maulana, A. (2019). Pengaruh Merek Dan Kemasan Terhadap Keputusan Pembelian Produk Teh Pucuk Harum Pada Siswa-Siswi Smkn 1 Jatisari.

McCarthy, E. J., \& D, W. (2002). Dasar - dasar Pemasaran. Surabaya:Erlangga.

Murty, D. (2015). Analisis Pengaruh Harga, Kualitas Produk Dan Citra Merek Terhadap Keputusan Pembelian Air Minum Dalam Kemasan Merek Pelangi Kemasan 600ml Di Semarang.

Ningsih, F., Nas, S., \& Syabrus, H. (2015). Pengaruh Kualitas Produk Dan Harga Terhadap Keputusan Pembelian Air Minum Dalam Kemasan (Amdk) Merek Aqua (Studi Pada Mahasiswa Program Studi Pendidikan Ekonomi Universitas Riau).

Nofrian, D. (2016). Pengaruh Citra Merek Dan Kualitas Produk Terhadap Keputusan Pembelian Air Minum Dalam Kemasan (Amdk) Aqua (Survei Pada Konsumen Di Kota Padang).

Nur Hidayat, K. (2017). Pengaruh Citra Merek, Kualitas Dan Harga Terhadap Keputusan Pembelian Air Mineral Merek Aqua (Studi Pada Mahasiswa Universitas Muhammadiyah Surakarta). 
Oladepo, O. I. and, \& Abimbola, O. S. (2015). The Influence Of Brand Image And Promotional Mix On Consumer Buying Decicion - A Study Of Beverage Consumers In Lagos State, Nigeria.

Puadah, A. S. (2015). Pengaruh Merek Dan Packaging Terhadap keputusan Pembelian Air Minum Dalam Kemasan (AMDK) Merek Aqua.

Selestio, R. (2013). Analisis Pengaruh Citra Merek, Kualitas Produk Dan Promosi Terhadap Keputusan Pembelian Air Minum Dalam Kemasan (Amdk) Merek Oasis (Studi Pada Konsumen Cv. Sinar Mas Murni Distributor Oasis Cabang Jakarta Selatan.

Sukotjo, H. (2016). Pengaruh Kesadaran Merek, Asosiasi Merek Dan Brand Image Terhadap Keputusan Pembelian Aqua.

Surabaya, B. P. S. (2019). Jumlah Penduduk Surabaya. (https://surabayakota.bps.go.id/,diakses pada Agustus 2019)

Tjiptono, F. (2008). Strategi Pemasaran (3rd ed.). Yogyakarta:Andi.

Tjiptono, F. (2012). Service Management Mewujudkan Layanan Prima. Yogyakarta:Andi.

Topbrand-award.com. 2016. Air Minum Dalam Kemasan 2016. (https://www.topbrandaward.com/en/2016/07/air-minum-dalam-kemasan-fase-2-2016/. Diakses pada 3 Agustus 2016)

Topbrand-award.com. 2017. Air Minum Dalam Kemasan 2017. (https://www.topbrandaward.com/en/2017/07/air-minum-dalam-kemasan-fase-2-2017/. Diakses pada 3 Juli 2017)

Topbrand-award.com. 2018. Air Minum Dalam Kemasan 2018. (https://www.topbrandaward.com/en/2018/07/air-minum-dalam-kemasan-2018/. Diakses pada 15 Mei 2018)

Topbrand-award.com. 2019. Air Minum Dalam Kemasan 2019. (https://www.topbrandaward.com/en/2019/08/air-minum-dalam-kemasan-fase-2-2019/. Diakses pada 20 November 2019)

Zemuy, H. (2013). The Impact Of Packing Design On A Purchase Decision Of Abyssinia Natural Spring Water. 